\title{
IT IS A LIVING THING: AN ESTONIAN TRADITION BEARER AND SUPERNATURAL BEINGS CALLED HALDJAD
}

\author{
Elizabeth Ann Berton-Reilly
}

\begin{abstract}
A living example of Estonian traditional ways is a seventy-something Estonian-American woman who has kept alive the beliefs of her ancestors - all living things have a spirit, and their spirits are part of the Creator. This includes believing in the haldjad, or Little People. This ethnographic study demonstrates that many traditional beliefs with pre-Christian elements continue to be a way of living, even in modern America. The subject was born in Estonia during World War II, and later lived as a refugee in one of the American-run camps with her mother and three siblings from August 1945 to May 1950. Even though she was very young when she left Estonia, she inherited the traditional beliefs of her ancestors through her mother, beliefs that sustained her through the harsh displaced persons' camps and on to America. Her belief system includes the haldjad, whom she sees as her guardians and guides, who often manifest themselves as the Little People. Believing in the Little People is interwoven with the traditional Estonian belief system that everything is alive and sentient. She discusses the major differences in life philosophies between the conquering Germans and the Estonians, mainly how the German invaders emphasized domination over the land, as opposed to the Estonian peasants who worked with the land. She sees her worldview as being universal, especially in indigenous cultures, saying: "What we call the old religion is not a religion at all. It is simply a way of seeing life and living."
\end{abstract}

Keywords: Estonian, ethnography, haldjad, Little People, oral history, preChristian, tradition bearer, World War II

\section{INTRODUCTION}

Johanna Keenan was born in Narva, Estonia, on June 14, 1941, the day that the Soviet regime deported ten thousand two hundred Estonians from their homes (Deportations). Keenan is a tradition bearer who came into a world of fear but has managed to retain her strong faith in the 'old ways'. (According to folklorist Peter Bartis, tradition bearers are people who "by virtue of their good memories, long lives, performance skills, or particular roles within a community, are often especially well qualified to provide information" (Bartis 2002 [1979]: 7). 
Despite World War II, the subsequent displaced persons' camps she lived in as a child, and the assimilation process in the United States, Keenan has held onto a traditional way of life most of us have never heard of. This paper will address that way of life and how Keenan has kept it alive.

Integrated into the Estonian old ways are the haldjad or the Little People. Through extensive interviews and additional sources, I will demonstrate how this belief in the Little People, along with animism, is still an integral part of the life of at least part of the Estonian population. I interviewed Keenan on September 26, 2014, using Skype as our medium. I have had subsequent communications with her, via email, which are also included.

I have chosen Keenan as my interviewee because her case illustrates well how practicing a certain belief system can constitute a significant part of identitybuilding. Her experiences and insights shed light on her understanding of the traditional Estonian way of life along with Estonian World War II history.

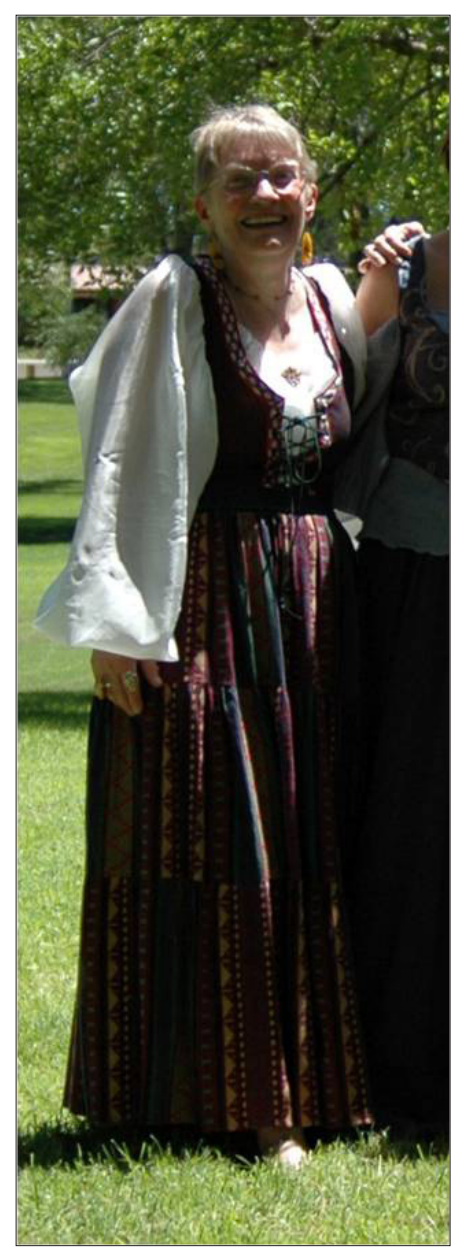

Knowledge of the Little People in Estonia is common and the word haldjad (plural, haldjas singular) means guardian or tutelary spirit, or fairy, elf, etc. in Estonian. In their tradition, the haldjad can also change from corporeal to non-corporeal beings. The narratives about the haldjad are considered 'teaching tales'. Keenan states, "Everyone knows that they, the haldjad, are around us all of the time."1

\section{JOHANNA KEENAN}

Keenan is a seventy-something-year-old Estonian American woman who follows the Estonian old ways. She was born in Estonia during World War II, and later lived as a refugee in one of the American-run camps (the Pond Barracks in Amberg, Germany) with her mother and three siblings from August 1945 to May 1950.

Prior to living in the camp, Keenan's father went missing in action. Her memories of this time are vivid, and despite the sadness and despair she faced, there was hope.

Figure 1. Johanna Keenan in 2008. Photograph from private collection. 
My father went missing in action in World War II, when I was three. I never really knew him, and so mother brought us up in her tradition. So that's why I know so much of this stuff. And she and I talked. I know that she talked about the old ways to all of us; I think I am the only one it took with. (J. K.)

\section{ESTONIA: A FEW FACTS}

Estonia is situated on the coast of the Baltic Sea, bordering Russia in the east, Finland (across the Gulf of Finland) in the north, and Latvia in the south. In the past, Germany, Denmark, Sweden, and Russia conquered this country countless times. The country stretches roughly 120 miles from north to south and is 150 miles wide, with forests still covering about 60 percent of the land. According to the viewpoint held by Keenan her people originally migrated from the northeast area of Siberia approximately eight to ten thousand years ago.

\section{ORAL HISTORY IN ESTONIA}

Estonian culture has oral history and folklore deeply embedded in it. The documentation of oral history in Estonia began in 1888, when Estonian folklorist Jakob Hurt published the material he received from his public appeal, requesting all kinds of folklore and oral history. Thousands of pages of handwritten material were sent to him and Matthias Johann Eisen in the following years. Later on, as of 1909, the Estonian Literary Museum started organizing such material in a more systematic way. Unlike most museums, the archives contained Estonian oral and written histories (Hinrikus 2009). It is a museum, continuing to this day, storing archival material on folk traditions and oral history.

Throughout the Soviet occupation, it was safer for a memory institution to bear the name 'museum' rather than 'archive,' since archives were closed (or at least half-closed) institutions, where access and use of materials was subject to closer surveillance. Furthermore, people never completely trusted any Soviet institutions. During the Soviet era, efforts to collect memoirs - if they were at all successful - yielded texts with the 'proper' ideological slant. Conversely, the regime did not trust the people, and archives were closed even to those who wished to research family trees. (Hinrikus 2009: VII) 
After 1989, when the Soviet occupation had ended, it was once again safe to publish life stories. In the years 1988-1992, the Estonian Heritage Society, in collaboration with the museum, sponsored a heritage collection campaign drawing in about 2,000 manuscripts (Hinrikus 2009: VIII).

As can be seen by the amount of oral histories that have been and continue to be archived, this culture values oral history and folklore. Johanna Keenan, a tradition bearer in her own right, carries on this oral tradition by translating and eventually publishing her mother's memoirs.

\section{BIOGRAPHICAL BACKGROUND}

Keenan comes from a long line of healers and tradition bearers. Her mother's family came from Hiiumaa, the second largest island in Estonia. Keenan explained the significance of the word Hiiu: "Hiiumaa simply means Hiiu Land, or land of Hiiu. One theory about the name is that it's a corruption of Hiie [hiis], which means sacred [forest]. Like the forest Mother grew up around which was called the Hiiemets or Hiie forest."

This was a sacred place and, at the time, a rather isolated island. The idea is that because her family originated in Hiiumaa, it was easier to become a tradition bearer. This could be in part because Hiiumaa is more isolated than the rest of Estonia. "People from Hiiumaa seem much stronger in their traditional ways than other areas. They were more isolated from outside knowledge and influence" (J. K.).

Keenan points out how her great-great-grandfather was a tradition bearer, and it had been passed down in the family to her great-grandmother, her grandfather, then her mother, and then herself. She states:

Mother's family was always considered outside the norm in the farm community they settled in. My grandfather was once described by a neighbor as having an incredible brightness of intelligence and soul / spirit. That's the only way I know how to translate the Estonian term.

Although Keenan and her family originated from Hiiumaa, she was actually born in Narva, Estonia, very close to the Russian border. Her parents came from very different backgrounds. Her ethnically German father came from a family who were part of the landowning class. Her mother's family were Estonian peasants - maa inimesed - she explains, which means land people.

Keenan pointed out that her father's family viewed Estonians as no better than livestock. Consequently, when he wanted to marry an Estonian, his family disinherited him. Although Keenan's father's parents were nice to her mother, they never did reinstate his inheritance. 
Keenan spoke affectionately about her mother throughout our interview. She mentioned how her mother was a sickly child, so instead of being brought up to be a farmer's wife she was sent to school to get an education. While in the city, her mother found that she could not fit into city life. However, when she returned to the country, the farm people no longer accepted her. Keenan feels that she has inherited this peculiarity from her mother. "I think I have always been with mother in that mindset, and I got the outlook of a person who has come from the land" (J. K.).

This inability to 'fit in' has affected Keenan most of her life. She explains that through her passion for reading, as she searched for other like-minded people in books. She found it through some writings such as those by the late Lakota writer, Vine Deloria Jr. Keenan states that "all of a sudden, reading his books, I found his was the same attitude toward the land, toward the spirits, toward everything else. It was like a parallel world, it was like wow, I am not the only one."

She mentions how a few years ago, her sister-in-law told her that the older she got, the more she was like her mother. She meant it as a compliment, and Keenan took it as one. She laughed out loud during our interview, when she explained that neither she nor her mother was 'civilized'. Keenan also said that her sister Mare, however, took after their father's family. Like siding with the victor, her sister "found her safety among the rich and the powerful. I find my safety as far away from the rich and powerful as possible. And mother was the same" (J. K.).

\section{THE WAR YEARS}

The year before Keenan was born, in 1940, during World War II, the Soviets took over Estonia and the republic fell. By July 1941, Nazi Germany had reconquered Estonia. By the end of 1941, the Soviets had deported some 11,102 Estonians to Siberia (Laar 2006). The Nazi regime forced Keenan's father to fight for them. The Germans finally fled in September 1944.

As noted before, Keenan was born on one of the largest deportation days in Estonian history - June 14, 1941. This day is considered a day of mourning for the Estonian people (Deportation). Keenan says:

In fact, my birth probably saved the family. The Russian soldiers came all across Eastern Europe on the night of June 14th, and they knocked on the door and you had time to get on some clothes and people were put into cattle cars and taken to Siberia. Anyway, mother went into labor early 
because of the rumors. And so we were in the hospital instead of home, where we were supposed to be. So that's what saved our lives at that time. My father didn't think we would be so lucky when they came back in 1944, and that's when we fled.

In 1944, the Soviets started an offensive against the Germans. By then, there was much understandable fear of the Soviets, which continued throughout their presence. "After the return of the Soviet regime in 1944, those left in Soviet Estonia lived on with fear-complexes instilled by what had been lived through and (up to Stalin's death in 1953) the continued anticipation of terror and repressions" (Hinrikus 2009). It was from this environment that Keenan and her family fled. In fact, she states in the interview, "When the Russians came in ' 44 we had to flee. Both my parents were under death sentence from Stalin, because Stalin killed or sent to Siberia almost everybody who had an education or was any kind of position of leadership or power." Keenan further mentions that before World War II, her father was "the equivalent of an executive vice president in charge of personnel in a textile factory, in today's parlance. ... Mother graduated the top of her class from Tallinn's art academy [Estonian Academy of Arts]. His position was more important to the Soviets as a danger to be eliminated. I never saw my father again."

Keenan and her family fled to Wiesenthal, Czechoslovakia, then known as Sudetenland or Germany's East Window, a small town about 280 miles west of the Czech border. She elaborates:

We fled by ship from Estonia to some port in Poland, went from there by train to Czechoslovakia where they had some higher mountains, partly because of me. I had TB [tuberculosis] and the higher, dryer air was better for me. We lived there in a town named Wiesenthal (I don't think it exists any more) till early August 1945, when the war was over and we again fled the Russians to the American sector of Germany. A train took us to Amberg where we were placed in the DP camps.

\section{5: POND BARRACKS CAMP}

At the end of World War II, there were probably over eleven million refugees (displaced persons or DPs) from all over Europe. Due to fears of the Soviet regime returning, 70,000 Estonians fled to the United States, Canada, Australia, Germany, and Sweden (Hinrikus 2009). 
The allies established refugee camps, which were mostly set up to give the refugees a place to live until relocation. These camps were places that offered food and shelter. (Despite this, sometimes there was not enough food to go around.) The conditions in camps were far from ideal and appeared to vary from camp to camp (Haukanõmm 2010).

In August of 1945, Keenan, her mother, and her three siblings reached the American-run Pond Barracks camp, an old German military camp located near Amberg, Germany. Keenan, who is an artist, describes the camp as follows:

Inside the DP camps everything was gray. It is the color of hopelessness and depression, probably very commonly seen that way. Apparently most all the people felt it though nobody talked about it. It was like living in a black and white movie. When we were allowed out of the camp, there was color; and more sharply so perhaps because inside it was so all-consuming.

While in this camp, Keenan's mother did her best to provide a semi-normal existence for her children. When allowed, they would often take walks in the nearby woods, and while on these walks, Keenan would feel that the spirits there were calling her. She recalls a time where she found a cave in the woods:

One time, we walked to a different place and it was almost like a wide arroyo. There was a cave and I wanted to go into it because it was calling me. I wanted it so bad and they tried to explain to me that I couldn't go in because it was dangerous, and I said, 'No it isn't dangerous! I need to go in!' I don't know what was there but I needed to go in. And I still remember that mother had one of the men pick me up and throw me over his shoulder, and I'm going, 'Let me down! Let me down! I need to go in!' . . I was probably five or six at most. [Laughter] Mother said I was always very stubborn. Ah man, I threw a temper tantrum like you wouldn't believe [Laughter].

The story she tells demonstrates her faith: in the woods she always feels safe and protected.

Throughout her time at the camp, she mentioned that although she did not consciously think about the haldjad, she nonetheless felt protected. To emphasize this point, Keenan laughingly mentions how her mother used to say that it took two angels or guardian spirits to protect her daughter - it would be too difficult a job for just one. 


\section{0: IMMIGRATION TO THE UNITED STATES}

In late May of 1950, through sponsorship of a Lutheran welfare organization, Keenan and her family immigrated to the United States - to Fargo, North Dakota. Prior to their arrival, her mother had taken the job of a cleaning woman in Minot, North Dakota. Unfortunately, while on board a ship en route, the man who would have been Keenan's mother's boss had an argument with a Latvian woman, and he exclaimed that he wanted "no more God-damned refugees" (J. K.). This of course led to a predicament - the Lutheran welfare people had no idea what to do with Keenan's family. In addition, since Keenan's mother spoke only Estonian, a little German, and some Russian, finding a job was difficult. Luckily, by January 1951, her mother landed a job as a stock clerk at Woolworths. Also fortunately, her boss spoke some German so they were able to communicate.

I enquired in the interview if her family was at all part of a larger Estonian community. Keenan mentioned that when they first arrived in Fargo, there were about sixty Estonians and that they would socialize with them. However, things went sour very quickly. Keenan speculates that as her mother was a widow raising four children, they were looking for excuses for not feeling any sense of responsibility for helping them. Hence, some of the Estonians in Fargo started a rumor that her mother was a "lady of the evening". She states, "You know when you are nine years old and you hear these things and realize that your own people reject you. You don't have the feeling that you really want very much to do with them. And I am afraid that I am still that way a lot."

The rejection did not end there, unfortunately. Keenan's mother applied for a job in New York State, but in order to take the job, she would have needed to borrow money, and she let the prospective employer know this via a letter and application. They waited over a year to hear back. Finally, after over a year (in which time the ad was still being posted) Keenan's mother found out that the woman whose desk her application had been on for over a year, had stated, "We're not in charity business" (J. K.).

This sense of isolation that her and her family felt in the United States was exacerbated by the fact that Keenan's mother was threatened several times by the welfare office that she would lose custody of her children if they were caught speaking Estonian, even at home. Her mother, who was in her forties when they immigrated to the United States, never mastered English. In fact, out of the three siblings, Keenan and her sister Mare are the only ones to have maintained fluency in Estonian. Keenan also mentions how none of their children (her son and her nieces and nephews) speak Estonian. She explains that after her mother died, she and her sister talked about translating her mother's diaries and memoirs: 
I told my sister, 'Mare, you're older, your Estonian is much better than mine, you translate them.' But a few months later, I got the whole thing in the mail (she lived in Topeka and I lived in Denver), and I called her up and said, 'Why are you sending me this?' She says, 'You're going to have to translate. You and mother lived in the same world. I know about your world, but can never enter it.' So that was very good practice translating from the Estonian into English. And I have learned a lot out of it for myself. It's kept the language alive. And I do still read and write it.

This living "in the same world" speaks volumes about the connections between Keenan and her mother. I asked Keenan if her sister was referring to the traditional beliefs here, and Keenan said yes, but it also included their life philosophy.

\section{ANIMISM AND KEENAN'S BELIEFS}

"Mother's joke always was that Estonians go to church four times in their lives: to get baptized, confirmed, married, and buried. The rest of the time they live the old ways" (J. K.). A large part of Keenan's beliefs stems from instinct - she says she knows when she is safe and when she is not. Despite the dangers of living in the camps as a child, she would wander off in post-war Germany on occasion and scare her mother. "Mother said, 'Where have you been? I've been worried sick!' I said, 'But Mother, why were you worried? I knew I was safe.' And this is kind of a feeling that I have always had. I know when I am safe and when I am not" (J. K.). Part of her sense of safety in the woods stems from her seeing the sacred in everything and everyone.

There are no actual rituals that we practice, but it is that we try to do everything in a sacred manner. This to me means doing thoughtfully and thankfully, whether it is talking to you, walking in nature, turning a piece of wood, doing taxes, washing dishes, or taking out the garbage. All is sacred. There is no separation to sacred and profane. That means even us. (J. K.)

Keenan describes her understanding of the overall philosophy of Estonian traditionalism. She states emphatically:

The old ways are simply a way of thinking and living life. Very like the Amerindians, the spirits are all around us and it is that which we honor. Essentially to walk your talk and have reverence for all life and try to keep in balance with all that surrounds you, that we as humans are the same as all other life, which, for us, includes what is usually considered inanimate life. 
Everything is alive, everything sentient is the crux of her belief system. She makes sure to note that not only the rocks and grasses are alive, but this belief system extends to machines as well. She elaborates by telling of her experiences of seeing when a machine does not like someone. "I have had experiences with machines that have liked somebody or don't like other people. You take the same machine and give it to somebody else and the reaction of the machine is totally different" (J. K.).

\section{A GENERATIONAL ELEMENT}

Because Keenan comes from a family of healers and tradition bearers, I asked if she thought that this belief system was generational; i.e. do certain generations follow the old ways more than others do. She responded in the negative, and made sure that I knew that she was only talking about herself and her experiences: "No, I don't think the beliefs are generational. I was talking about how I learned. I do think they are more familial or regional. While every farm family probably believes/knows about the ways, some beliefs are much stronger than others."

\section{LOCALITY}

I questioned Keenan about the haldjad narratives, asking if the narratives were found only in certain areas of Estonia. She answered that often they differed by areas, and then discussed the Estonian sacrificial stones, which are stones where offerings are sometimes left for the haldjad or Little People, and/ or which are used for healing purposes (Tvauri 1999).

"There is one old way what is called the 'sacrifice stone', which sounds horrible, but it's a stone, usually natural, that has a slight indentation in the center. And there you always give food as a thank you. There are hundreds of them all over Estonia" (J. K.). As a fascinating side to this, students at one of the Estonian universities now burn their lecture notes on one of these stones after their exams (Bousfield 2011 [2004]). 


\section{THE HALDJAD, ESTONIAN LITTLE PEOPLE}

According to Keenan, the Estonians do not see the haldjad or Little People as good or bad per se; the emphasis is on how we treat them, what is in our hearts. This is in contrast to the Irish who (like many other cultures) distinguish between good and bad Little People.

To me there was just the certain knowledge that [is how] these things [the haldjad] were - the little spirits / people who could change their appearance and would often test you to see if you were of good heart or not. This usually happened in the forest. There were also stories of darker little people who tempted you to great riches in their underground kingdoms, but even there it became a test as to whether you were greedy or not, and how far you would go. (J. K.)

This Estonian animist tradition ties directly into the Little People. They are spirits who many Estonians consider as teachers and guides. According to the Estonian traditional belief system the haldjad help people, especially children, to distinguish right from wrong. In addition to that, the Little People - the haldjad - test people to see if they are living in a traditional, respectful manner, "in the old ways; having respect, being helpful, willing to share what we have" (J. K.). She also mentions that when she does speak to the haldjad, she talks to them in either Estonian or English, depending upon what she is thinking about at the time.

In other cultural narratives, the Little People oftentimes wear the traditional clothing of that culture, and in some instances speak the traditional language. However, Keenan points out that as to Estonian culture, she does not know if this is the case. Instead of traditional clothing, the Estonians see the haldjad as "ragged and often dirty" (J. K.).

In order to gain insight into the Little People in Estonian lore, it is important to know that the word haldjas has a dual meaning. Keenan explains to me that the word haldjas means both a spirit and Little People. She explains that "there is no differentiation between the spirit world and the world of the fairies or the Little People. And this is just such common knowledge that you don't even think about it". 


\section{NARRATIVES OF HALDJAD}

Keenan mentions how there are many stories that have a similar theme. Belief in the Little People is interwoven with the Estonian belief system, not something seen as separate. According to Keenan, Estonians see the Little People as alive and real. Nature in its entirety is seen as sentient, and the haldjad are part of it.

As Mother told us, the spirits / Little People responded to whoever was there. They could change form and often tested people who entered their realm. If you were found wanting you came to harm; if not, they opened their coffers and powers to you. (J. K.)

Not much has been written about the Estonian old ways until very recently. Keenan states as an explanation, "Mother used to say, 'What Estonians hold most dear, they are most quiet about'." There is the fear of someone taking their beliefs and using them against them. Their very soul would be robbed.

She goes on to emphasize that the narratives of the haldjad are teaching tales passed down from one generation to another. They are tales of how to conduct oneself and of what happens if one is not respectful of others or nature. To emphasize, Keenan tells the story of the three brothers:

Two brothers are highly intelligent, aggressive, and the father sends them on an errand where they have to go through the forest. The oldest one goes and there is a man lying down and he's hurt. The first son walks past without ever looking at him. A little bit later, he comes across a woman who asks for a crust of bread because she's starving. (These are actually Little People in disguise). He says, 'Oh, you old hag, why don't you go and earn your own bread?' and goes on. Well, he gets stuck in the forest somewhere and he never can get done what he is supposed to do. The second brother has basically the same experience. When neither one comes home everybody gets worried. The third brother, who is considered a simpleton, is different from the others; he is not aggressive. He keeps asking his father to go and finally the father says 'go, go, go!' And so he comes to the hurt man, and helps the man. And makes sure that he is ok, and he takes some of his food and gives it to the man and then he goes on and meets the woman. And he gives her not only a crust of bread but the rest of the bread that he has. And everything goes well for him. They both bless him, and whatever he needs is given to him almost before he thinks to even ask for it. And he is able to accomplish the deed, and he is usually able to free his brothers. And they all can go home. 
A significant theme in this narrative, which reflects traditional Estonian views, is that the family sees the sensitive brother as a simpleton and usually dismisses him. However, he is inevitably the one who has the deepest connection to the haldjad. "He is the one who is in touch with the real, with the gentle, the caring side of us" (J. K.). This dichotomy illustrates the division between the old ways (as being simple-minded) and the new ways as being more sophisticated and aggressive.

\section{WHAT HALDJAD MEAN TO KEENAN}

Keenan sees the haldjad as being her guides as well as her guardians. "As guiding spirits, the Little People play an integral part of my life" (J. K.). To her, it does not matter if they are spirits or corporeal beings; what matters is treating them with respect. I asked her about having set rituals - such as putting out a bowl of cream like the Irish do - and she responded in the negative. "I'm not required to do exacting rituals to appease them. They understand my heart and ritual is usually a dead thing" (J. K.).

She goes on to emphasize how she views ritual as a product of trying to duplicate a numinous experience:

For example, someone has a numinous experience, finds it wonderful and wants to repeat it. So he tries to remember exactly what he did before the experience, and keeps duplicating it, thinking that will get him there. After a time, the ritual of trying to relive the numinous experience becomes standardized and that is eventually all that remains. The experience itself becomes a miraculous happening which is impossible to attain by mortal man and so mostly forgotten.

Instead of formal rituals, her experiences are much more spontaneous when she least expects them.

Sometimes it's the incredible beauty of the color of the sky, or... seeing a hawk driven off by a sparrow, when I had just been defeated by the system and needed courage. These times are as clear to me as the day it happened; there is a tightening of my chest to the point that it almost hurts and tears in my eyes from the wonder of it. (J. K.)

Along with a lack of set rituals, Keenan also emphasizes that she does not have personal experiences with the haldjad in the traditional sense of the word. Instead of seeing the Little People, as others have in other traditions, it is more 
of a feeling of safety in nature. This feeling has continued throughout her life. She mentions that when she lived in Denver a few years back, she used to hike in the mountains and never felt afraid. "I have always felt that I was being watched over and cared for. And that I wasn't afraid of the animals, that I knew that I was ok. And this is from the time I can remember" (J. K.).

Keenan said that the Estonian farmers do have rituals that demonstrate the traditional belief system, especially that of giving back to nature. They had special days of the year, like when the first crops would come in. Estonian farmers treated these crops differently than others, and it was expected that some of it would be returned to the land. "The whole idea was you normally planted three times what you expected to harvest. 1/3 was for you, 1/3 probably wouldn't grow, and 1/3 would be for the birds and the other animals, the wild" (J. K.).

Giving back to nature is also an important value passed down to Keenan. She mentions that whenever her grandfather needed to cut a tree down, he would talk to the tree, thanking it, and make sure that he planted three trees for each one he had cut down.

Another strong aspect of her belief system is being flexible in life. She gives a tale of an oak tree and a blade of grass, which her mother had told to her as a child. This story illuminates the importance of not only flexibility, but also that size does not matter.

The oak tree was always looking down at the blade of grass and saying, 'You down there, look how weak you are, look how insignificant you are. When the wind blows, you get blown down, and when it rains you almost drown with the water,' and this went on for a long time. Then one night there was a storm, and the wind blew and the rain came; it was an incredible storm. The oak tree got blown around, the blade of grass got totally mashed into the soil, and the oak tree kept laughing. 'Look at you!!! Look at you, look at you ha-ha!' Then came a tremendously strong gust, and the oak tree broke and went down. After that rain and the storm went over, the blade of grass stood up, but the tree never did. And I think that this is kind of an attitude that you live with, you know you're little; you're insignificant, that you have to bend, you have to accept the thing that comes and not try to fight always. Because fighting you're going to break, and bending you will survive to live again. (J. K.)

This narrative also illustrates the Estonians' survival of 700 years of slavery, and both Nazi and Soviet regimes. According to Keenan, the Estonian people, by sheer determination and flexibility in the circumstances, were able to outlive the 'oak' of tyranny. 


\section{THE ROLE OF LITTLE PEOPLE IN KEENAN'S ART}

One of the roles that the haldjad play in Keenan's life is manifest in her art. Keenan is an amateur sculptor and also uses other artistic mediums. She finds that the haldjad play a definitive role in her inspiration. When she begins work at a sculpture, she has no idea what she will create, she simply feels guided by the haldjad. "Nothing exists at this point except my hands and the clay. I feel the sculpture comes through me rather than from me. After the initial forming, I come back to myself and it is a matter of eye and hands/tools to refine the form" (J. K.).

\section{KEENAN'S BELIEFS AND HER CONNECTION TO HER PAST}

Keenan's beliefs connect her to her Estonian past as well as tie into her family's future. "Absolutely, the belief system connects me to the land and my ancestors. Remember, the old ways are simply a way of thinking and living. It is not a religion" (J. K.). Keenan mentioned that when her son, niece, nephew, and great-nephew went to Estonia last summer, her son, niece, and her greatnephew felt very connected to the people and the land. They were home. However, her nephew seemed not to connect at all, nor did he seem to feel anything other than a superior stranger's interest, especially in the old churches; he wore T-shirts with Christian logos. Keenan stated, "He was and remained an outsider, even to the family there."

Keenan went on to discuss how these old ways have been passed down to a new generation, even though there was no conscious teaching of that knowledge. "I think I taught much like Mother taught me, just by the way I loved and related to others" (J. K.). Keenan's ex-husband took her son Bear from her when he was a little boy. According to Keenan, his father tried to bring him up as a Catholic, but never succeeded. When her son was in his teens, a Southern Ute elder adopted him, and he is practicing their ways, which is a parallel tradition to the Estonian old ways.

Keenan's niece, in learning touch healing, is also learning the old ways on her own, often talking to Keenan, trying to find answers to the questions she has. Once when Keenan talked to her nephew about there being much more in the world other than just the narrow vision of Christianity, he answered that he had chosen the box of being a minister and did not want to think outside of that. 


\section{KEENAN AND ESTONIANS TODAY}

To answer the question about with whom Keenan discusses her belief system, she says that she does not talk much to others about what she believes. In fact, it is rare that she shares her beliefs with anyone. She recalls that when she did in past talk to people about it, she got a look that said she was ready for the loony bin.

This is not an acceptable idea in today's culture, though I wish it were. I think then elders would be much more respected and not written off as just old people who need to be put in places where they are not seen or heard; when quality of life becomes more important than its length. (J. K.)

She explains further:

I tried very hard to believe [in Christianity] but it did not take, I was too old when I came to it. And so my outlook on life - it's about like a city slicker and a farm hand trying to have them have a conversation, to understand each other. They really speak a different language. There is no communication.

However, recently she spoke about her beliefs to a young man who was her client (she works as a tax accountant):

It's like today; a young man (mid- to late 40s) came to get some tax things done and as often happens with him we started talking. I shared, not necessarily talking about Little People, but ideas that I live by. He surprised me several times by telling me that I'd given him definite ideas as to how he should direct his energy and thinking, of how he also was a fraid of sharing his thinking with others as he'd gotten ridiculed so often. I do believe that I helped him, gave him courage and some new ideas to think about. I feel very good about that. I think this is what I need to doshare some ideas and listen to whether there is a receptive spirit. I think there are many people searching for something, but don't even know what it is they search for. I can remember when too rarely someone was a light for me; how important it was that they trusted me enough to share their thoughts. (J. K.)

When asked if her interactions with the haldjad are the same as those of other Estonians, she stated that she has no idea how other Estonians relate to them. She said her mother and grandfather had raised her this way. However, her siblings wanted to become Americanized completely and ignored the old ways. When she did try to discuss the old ways with her siblings, she found that their viewpoints were radically different. 
However, by talking to one of her cousins in Estonia in 1988, Keenan was able to see her belief system as a way of life.

One of my first cousins said, 'You know, we wanted rid of the Russians, not for political reasons,' (because Estonians are very apolitical)... 'We want rid of them because they are destroying the land. Without the land there is no life.' All of the sudden I knew: what we call the old religion, is not a religion at all. It is simply a way of seeing life and living. (J. K.)

\section{GERMANY AND ESTONIA}

Keenan discussed the major differences in life philosophies between the conquering Germans and the conquered Estonians. She said the German Teutonic Knights came to Estonia in 1209 and it took 75 years to conquer the land. They never did Christianize it. She said that the Roman senator and historian Tacitus, in the first century CE, wrote about the Estonians (he called them the Fenni), explaining the Romans' fear of going into those barbaric woods containing wild animals and people who were astonishingly savage and disgustingly poor, and were wearing animal skins:

They have no proper weapons, no horses, no homes. When they went hunting, they pulled their children and old people in slings up into the trees, and the women hunted right alongside of the men. I mean, can you imagine that? And he says that the people are so content that they do not need to pray for anything. (J. K.)

The Germans, Keenan states, also fear the deep forests. This is because Germanic peoples originated from the Russian steppes with no forests. In the interview, she recalls:

It really was brought home to me by my great-nephew's story. He went with his mother, my niece, and my son to Estonia. When they went to the islands where my family originated, Hiiu Island, there was a road and there were solid trees, 75-80 feet tall on both sides. He got so scared that he was claustrophobic, because he'd grown up in North Dakota, on the plains. He could not handle the forests.

Keenan explains that some Estonians, instead of embracing the old traditional ways, tend to relate to their victors. Plenty of this has to do with the environment an Estonian comes from. "It is the farm people mostly that pass the stories down. The people who moved into the city tried, we call it, to become Germanified. 
Because when you have a people above ruling you, you try to emulate them" (J. K.). A large part of this behavior is based on survival, Keenan explains, and continues that as parents give their children more Germanic names, the children are more likely to blend in and have a better chance in life.

\section{KEENAN'S COMMENTS ON OTHER WORLDVIEWS}

Keenan discusses how the most profound difference between the Estonian old ways and Christianity reflects in people's view of the land. She mentions how Estonians traditionally work with the land, and in Western societies (mostly in Christianity) there is an attitude of dominating the land. This idea of domination also extends to what they view as lesser beings than them, be it other people or animals. Her way, she explains, is profoundly different.

In my ways I have to try to understand the land and respect it, and share the gifts of the earth with those around me, whether human or animal. The 'new' way says that I don't have to bother understanding anything and that I have the right to take whatever I feel I want, no matter how it affects everything around me.

Keenan makes further connections between belief systems and how we treat the earth. For instance, in the traditional ways, the biggest sin is not a matter of not properly following a dogma, but that of waste. Her belief system is about harmony - living with the earth and living in balance with nature. She explains how in Estonia today wild animals still live in the woods - bears, wolves, deer, elk, bobcats (i.e. lynx) - in harmony with people. Very rarely are there any confrontations.

Now, part of what is being done is, on every road that cuts through the country, there are wilderness copses on either side, every kilometer one is on one side and one is on the other side, so it's almost like a corridor for the animals to go from one place to another. (J. K.)

Her younger brother, Karl, was a preacher who wanted to 'save' the Mandan Native people of North Dakota. He once said to Keenan, "I know that you have done a lot of studying of the old ways... How did the Estonians learn to live with Christianity and the old ways together?" And Keenan responded, "Well, you can't. The two ways are irreconcilable. One says to live over the land and the other says to live with the land. We have the veneer of Christianity but live the old ways." Keenan then emphasizes her point by saying, "I think that this is all to do with the spirit world and the fairies and all that. It's a living thing." 
She also mentions an article she read in 1997, which said that despite such wild animals as bears and wolves in the forest, very rarely is there a problem with people and these animals in Estonia. She describes how an American visiting Europe did a study of wolves killing people in Finland. According to his study, there have been seventy-five instances of wolves killing people in a hundred years. "And in every case there was a man with a gun. Every one! A man with a gun! There were no children, no women, just men with guns, hunting" (J. K.). This could be seen as an example, like the haldjad, of the fact that by respecting the creatures in the forest you will be okay, but if you do not, you could be killed.

\section{VISITING ESTONIA IN 1988}

In 1988, Keenan and her older sister, Mare, visited Estonia. It was 44 years since they had fled. There was some trepidation from family members, who were worried that the Russians would keep them there. Russia did not recognize expatriation, even though they were both American citizens. However, Keenan was not worried. She explains, "Our family was so scared, what if they kept us? And I figured two middle-aged women who weren't of any importance at all; why would Russia create an international incident over somebody like us?" This statement she made is another example of her deep sense of safety - she knew intuitively that they would be safe in Estonia.

While in Estonia, she visited her grandfather's farm with her cousins, which at the time was illegal. She explains that her sister did not go for that very reason, but she did, and she was glad she did.

My sister didn't dare go, but I did. [Laughter] And it was nice, it was really nice. I didn't remember any of it [the farm], because I blocked my memory of the first four years of my life. But it all felt right. My body remembers, even though my mind does not. (J. K.)

\section{KEENAN'S COMMENTS ON OTHER ESTONIAN PRACTICES}

Keenan gives a cultural context to the Estonian traditional belief system. She sees her worldview as being universal, especially in so-called primitive societies. She emphasizes this point by mentioning meeting a woman from England recently, who shared some of her beliefs regarding the land "and its manifestations" (J. K.). 
I think this is very alive in most all 'primitive' cultures, no matter if it's in the Americas or Asia or Africa. Where life is simpler and technology has not intruded as much. Of course there are always people from these cultures who see the possibilities for power in the new and attempt to use that to gain power for themselves. Maybe that is the difference between the two. Our old ways discourage power over others, whereas the newer ways encourage it. We had the equivalent of the Lakota peace chiefs. We called them village elders. The only real power they had was that of persuasion. It was more a place of responsibility where the elder must find ways of helping all the people of the village/community, mostly by his own example, but often out of his own pocket. (J. K.)

\section{ANIMISM IN ESTONIA TODAY}

Keenan is not alone in her beliefs. According to the article, "Some Estonians Return to Pre-Christian Animist Traditions", by Ellen Barry, there is a resurgence of the traditional belief system in Estonia. Barry explains that in 2008 a group of people visited the famous Witch's Well (a sinkhole) in Tuhala, Estonia, when it erupted. "Geologists believe that after flooding rains, underground water pressure builds to the point that water shoots up out of the ground, usually for a few days" (Barry 2008). This transpired after three years of being silent (ibid.).

The Witch's Well of Tuhala got its name from a legend, according to which the Tuhala witches were taking a sauna underground. By whisking themselves with birch branches (which is a traditional practice), they caused quite a commotion. Every few years, this sinkhole erupts. When it does, it lasts a few days and people from all over Estonia travel to see it (ibid.).

Regardless of the reason, it demonstrates that some of these beliefs are still very much alive in Estonia. One woman, who was interviewed for that article, put it succinctly (and not unlike Keenan): “Estonia is full of natural magic,' said Mari-Liis Roos, 37, a translator who had come to Tuhala with her husband and son. 'It's hard to describe. Sometimes you don't want to explain these things, because it is so personal"' (ibid.).

According to Kathryn Rountree, in her article, "Neo-Paganism, Native Faith and Indigenous Religion: A Case Study of Malta within the European Context", Maausk (the traditional pre-Christian Estonian religion) is making a comeback. "Embracing Maausk is a strategy for asserting a locally distinct ethnic identity alongside a fairly new pan-regional identity as a member of the European Union, to which Estonia was admitted in 2004" (Rountree 2014). 


\section{CONCLUSION}

Through the world war, camps, immigration to the United States, and finally settling in a small town in New Mexico, Keenan has held steady to her traditional beliefs. She sees them as a way of life and a way of being. Her faith, and the faith of the Estonian tradition bearers, has taken them through one dictatorial regime after another into the 21 st century.

Today, Keenan is much happier and there is a community of people who love her. Instead of simply being told that she is 'weird', the people in her life today celebrate her wisdom. In the past, she explains, she felt that she had to be silent. "My mother said that she has never known a human being as silent as I was. I learned to be silent because, hey! It gets old being told you're weird" (J. K.). Thankfully, for the rest of us, she no longer has to be silent.

Maybe the most important thing that's happening here is that I am actively thinking and feeling the ways of my people and the spirits. That it feels safe and good to share them. I tended to live as a hermit much of the time, thinking that I am very alone. It was scary to talk of my past and my ideas. But as the old saying goes, if not me, then who? (J. K.)

Very significantly, many elements of this belief system survived centuries of the onslaught of various tyrannies. The Estonian traditional people, like Keenan, have gone through one political and religious metamorphosis after another, and yet are still able to hold true to their beliefs. Despite all the other outside influences, there is still a deep reverence and respect for the land, as well as these ancient beliefs. Perhaps, in the end, the Little People still prevail.

\section{NOTE}

1 Hereinafter, all the citations originate from personal communication with Johanna Keenan and are given word for word, including slips of the tongue. Her initials are added only where not explicitly understood from the text that these are her words. 


\section{REFERENCES}

Barry, Ellen 2008. Some Estonians Return to Pre-Christian Animist Traditions. New York Times: Europe. November 9. Available at http://www.nytimes.com/2008/12/09/ world/europe/09iht-estonia.4.18535971.html?_r=0, last accessed on June 29, 2016.

Bartis, Peter 2002 [1979]. Folklife and Fieldwork: An Introduction to Field Techniques. Washington, DC: Library of Congress. Available at https://www.loc.gov/folklife/ fieldwork/, last accessed on June 29, 2016.

Bousfield, Jonathan 2011 [2004]. The Rough Guide to Estonia, Latvia \& Lithuania. London: Rough Guides Ltd.

Deportations $=$ Soviet Deportations from Estonia in 1940s. Available at http://estonia. eu/about-estonia/history/soviet-deportations-from-estonia-in-1940s.html, last accessed on June 27, 2016.

Haukanõmm, Kaja 2010. Life in Displaced Persons' (DP) Camps. Estonica: Encyclopedia about Estonia. Available at http://www.estonica.org/en/Life_in_Displaced_ Persons_DP_camps/, last accessed on June 29, 2016.

Hinrikus, Rutt (comp.) 2009. Estonian Life Stories. Edited and translated by Tiina Kirss. Budapest \& New York: Central European University Press.

Keenan, Joanna. Personal interview. September 26, 2014.

Laar, Mart 2006. Estonia Today: Deportation from Estonia in 1941 and 1949. Fact Sheet June 2006. Available at http://vm.ee/sites/default/files/content-editors/ web-static/128/Deportations_from_Estonia.pdf, last accessed on June 29, 2016.

Rountree, Kathryn 2014. Neo-Paganism, Native Faith and Indigenous Religion: A Case Study of Malta within the European Context. Social Anthropology / Anthropologie Sociale, Vol. 22, No. 1, pp. 81-100. DOI: 10.1111/1469-8676.12063.

Tvauri, Andres 1999. Cup-Marked Stones in Estonia. Folklore: Electronic Journal of Folklore, Vol. 11, pp. 113-169. DOI:10.7592/FEJF1999.11.stones. 